\title{
TANDEM COMPRESSION OF MEDULLA SPINALIS AND CAUDA EQUINA
}

\author{
Zhelyazkov Christo, ${ }^{1}$ Davarski Atanas, ${ }^{1}$ Kitova Tanya, ${ }^{2}$ Kehayov Ivo, ${ }^{1}$ Kitov Borislav ${ }^{1}$ \\ ${ }^{1}$ Department of Neurosurgery, Medical University, Plovdiv, Bulgaria \\ ${ }^{2}$ Department of Anatomy, Histology and Embriology, Medical University, Plovdiv, Bulgaria
}

Primljen/Received 21. 01. 2015. god.

Abstract: Objective: To analyze and present cases of tandem compression of medulla spinalis and cauda equina.

Material and Methods: The subjects of observation were four patients with simultaneous compression of medulla spinalis and cauda equina, admitted to the Neurosurgery Clinic of the St George University Hospital, Plovdiv, Bulgaria during the period March 2012 - March 2014. The average age of the patients was 60.5 years $(47-72)$.

In one case, left-sided paramedian herniated discs were found at levels $\mathrm{L}_{1-2}$ and $\mathrm{L}_{4-5}$ combined with a concomitant stenosis, in another case - right-sided paramedian herniated discs on the level of $\mathrm{Th}_{12}-\mathrm{L}_{1}$ and a degenerative stenosis at level of $\mathrm{L}_{3-4}$, in the third case - pronounced degenerative compression at level $\mathrm{Th}_{7-8}$ and a central stenosis at level of $\mathrm{L}_{4-5}$, and in the last case - degenerative stenosis at level $\mathrm{L}_{3-5}$ and spinal meningioma at level $\mathrm{Th}_{9-10}$.

Results: The clinical signs of the simultaneous compression of the spinal cord and cauda equina have been examined. These signs may mislead the physician in the diagnosis of the spinal lesion, thus, resulting in inappropriate surgical strategy.

Conclusion: The involvement of the spinal cord must be clinically confirmed to rule out lesions in the thoracic region. When the lumbar imaging examinations are inconclusive or cannot explain the clinical symptoms of a certain patient, it is advisable to perform a magnetic resonance imaging of the entire spine.

Key words: tandem compression, spinal tumor, thoracic stenosis, lumbar stenosis.

\section{INTRODUCTION}

The term 'tandemspinal stenosis' was first introduced by P. Teng and C. Papatheodorou in 1964 in an attempt to describe the simultaneous compression in
Prihvaćen/Accepted 18. 02. 2015. god.

the cervical and lumbar regions (1). Subsequently, several publications have been published in the specialized literature that discuss the simultaneous compression in the thoracic, thoraco-lumbar and lumbar regions $(2,3)$, resulting from degenerative stenosis (4), disc herniation (3), arachnoid cysts (5) or spinal tumors (6). In some cases, surgeons first operate on the lumbar lesion due to its apparent clinical and imaging manifestation. Nevertheless, neurological complications are sometimes possible resulting from the superiorly located lesion (3).

\section{Objective}

Analyzing and presenting cases of tandem compression of medulla spinalis and cauda equina.

\section{MATERIAL AND METHODS}

We present 4 cases ( 3 male and 1 female) that were treated in the Clinic of Neurosurgery at St George University Hospital, Plovdiv, Bulgaria between March 2012 and March 2014. The mean age of the patients was 60.5 years (47-72). All cases have long-lasting medical history of back pain irradiating unilaterally or bilaterally to the legs which was subsequently overlapped by stiffness and weakness in the lower extremities (Table 1).

In one of our cases, the clinical presentation was dominated solely by lower back pain accompanied by radicular sensory and motor deficit. All other three cases presented with combined symptoms of central and peripheral system damage (Table 2).

\section{CASE DESCRIPTIONS}

All four cases are systematically presented on Tables 1,2 and 3 . 
Table 1. Affected spinal segments and initial symptoms

\begin{tabular}{|l|l|c|c|}
\hline Patient/Gender/Age & \multicolumn{1}{|c|}{ Reported initial symptoms } & $\begin{array}{c}\text { Level of compromise } \\
\text { of caudaequina }\end{array}$ & $\begin{array}{c}\text { Level of compromise } \\
\text { of medullaspinalis }\end{array}$ \\
\hline 1. Female, 72 & $\begin{array}{l}\text { Back pain, left leg pain and } \\
\text { numbness }\end{array}$ & $\begin{array}{c}\text { Stenosis } \mathrm{L}_{4}-\mathrm{L}_{5} \\
(\mathrm{HIJ}+\mathrm{HYL}+\mathrm{DH})\end{array}$ & $\begin{array}{c}\text { Stenosis } \mathrm{L}_{1}-\mathrm{L}_{2} \\
(\mathrm{HIJ}+\mathrm{HVL}+\mathrm{DH})\end{array}$ \\
\hline 2. Male, 58 & $\begin{array}{l}\text { Pain in the thoraco-lumbar region } \\
\text { and leg stiffness }\end{array}$ & $\begin{array}{c}\text { Stenosis } \mathrm{L}_{3}-\mathrm{L}_{4} \\
(\mathrm{HIJ}+\mathrm{HVL}+\mathrm{DH})\end{array}$ & $\begin{array}{c}\text { Disc herniation } \\
\text { at } \mathrm{Th}_{12}-\mathrm{L}_{1} \text { level }\end{array}$ \\
\hline 3. Female, 65 & $\begin{array}{l}\text { Pain in the back and legs. } \\
\text { Numbness across } \mathrm{L}_{5} \text { and } \mathrm{S}_{1} \\
\text { dermatomes bilaterally }\end{array}$ & $\begin{array}{c}\text { Stenosis } \mathrm{L}_{4}-\mathrm{L} 5 \\
(\mathrm{HIJ}+\mathrm{HYL}+\mathrm{DH})\end{array}$ & $\begin{array}{c}\text { Stenosis } \mathrm{Th}_{7}-\mathrm{Th} 8 \\
(\mathrm{HIJ}+\mathrm{HYL}+\mathrm{DH})\end{array}$ \\
\hline 4. Female, 47 & $\begin{array}{l}\text { Pain in the back and legs. } \\
\text { Progressive weakness in the legs }\end{array}$ & $\begin{array}{c}\text { Stenosis } \mathrm{L}_{3}-\mathrm{L}_{4} \text { and } \mathrm{L}_{4}-\mathrm{L}_{5} \\
(\mathrm{HIJ}+\mathrm{DH})\end{array}$ & $\begin{array}{c}\text { Meningioma } \\
\text { at } \mathrm{Th}_{9-10} \text { level }\end{array}$ \\
\hline
\end{tabular}

HIJ — hypertrophy of the intervertebral joint; HYL — hypertrophy of the yellow ligament; HVL — hypertrophy of the vertebral lamina; DH — disc herniation;

Table 2. Neurological status of the patients at hospital admission

\begin{tabular}{|c|c|}
\hline Patient/Gender/Age & Neurological status \\
\hline 1. Female, 72 & $\begin{array}{l}\text { Lumbar vertebral syndrome: Possitive Lassegue sign at } 30^{\circ} \text { on the left. Pain and hypest- } \\
\text { hesiaacross } \mathrm{L}_{2}-\mathrm{S}_{1} \text { drematomes on the left. Loss of knee-jerk and ankle-jerk reflexes on } \\
\text { the left. Fibular nerve plegiaand tibialnerve paresis on the right side (Grade Con the } \\
\text { Frankel Scale). Hypotrophy of the muscles of the left thigh and calf. }\end{array}$ \\
\hline 2. Male, 58 & $\begin{array}{l}\text { Thoraco-lumbar vertebral syndrome. Pain and hypesthesia across } \mathrm{L}_{5} \text { and } \mathrm{S}_{1} \text { dermato- } \\
\text { mes bilaterally. Increased knee-jerk and ankle-jerk reflexes. Positive Babinski sign bi- } \\
\text { laterally, latent inferior paraparesis (Grade Don the Frankel Scale). }\end{array}$ \\
\hline 3. Female, 65 & $\begin{array}{l}\text { Thoraco-lumbar vertebral syndrome. Pain and hypesthesia across } \mathrm{L}_{5} \text { and } \mathrm{S}_{1} \text { dermato- } \\
\text { mes bilaterally. Inferior paraplegia (Grade Aon the Frankel Scale). Positive Babinski } \\
\text { sign bilaterally. Conductive hypesthesia distally from Th9 dermatome. Bowel and } \\
\text { bladder retention. }\end{array}$ \\
\hline 4. Female, 47 & $\begin{array}{l}\text { Lumbar vertebral syndrome: Pain and hypesthesia across } \mathrm{L}_{5} \text { and } \mathrm{S}_{1} \text { dermatomes on the } \\
\text { left. Inferior spastic paraparesis, more severe on the left (Grade Con the Frankel Scale). } \\
\text { Increased knee-jerk but diminished ankle-jerk reflexes. Positive Babinski sign bilater- } \\
\text { ally Conductive hypesthesia distally from } \mathrm{Th}_{12} \text { dermatome. }\end{array}$ \\
\hline
\end{tabular}

Table 3. Patients' neurological outcome

\begin{tabular}{|l|l|}
\hline Patient/Gender/Age & \multicolumn{1}{c|}{ Neurological outcome } \\
\hline 1. Female, 72 & $\begin{array}{l}\text { Substantial relieffrom the pain and vertebral syndromes. Mild reduction of the sensory } \\
\text { deficit. Reduction of the right-sided fibular palsy and tibial paresis. }\end{array}$ \\
\hline 2. Male, 58 & $\begin{array}{l}\text { Substantial relief from the pain and vertebral syndromes. No motor and sensory deficit } \\
\text { of the lower extremities (Grade Don the Frankel) Persistent hypesthesia across } \mathrm{L}_{5} \text { and } \\
\mathrm{S}_{1} \text { dermatomes. }\end{array}$ \\
\hline 3. Female, 65 & $\begin{array}{l}\text { Postoperative recovery was satisfactory with alleviation of the vertebral and radicular } \\
\text { syndromes together with reduction of the inferior paraplegia to Grade Caccording to } \\
\text { Frankel Scale. Bowel and bladder disturbances were persistent. }\end{array}$ \\
\hline 4. Female, 47 & $\begin{array}{l}\text { The neurological examination at 24th postoperative month revealed substantially im- } \\
\text { proved neurological function to Grade D on the Frankel Scale; substantial relief of the } \\
\text { pain syndrome; persistent hypesthesia across the left } \mathrm{S}_{1} \text { dermatome, absent left an- } \\
\text { kle-jerk reflex and mild difficulty in the plantar flexion of the toe resulting from the pe- } \\
\text { ripheral damage due to the lumbar pathology. The patient is able to perform her previo- } \\
\text { us duties. The postoperative MRI of the thoraco-lumbar spine showed no tumor reoc- } \\
\text { currence and adequate decompression of the lumbar spinal stenosis. }\end{array}$ \\
\hline
\end{tabular}




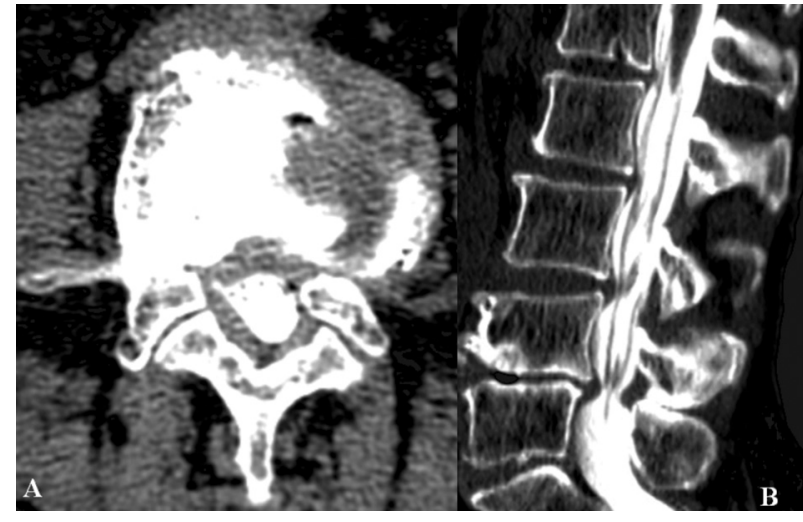

Figure 1. CT-assisted myelography: (A) axial view at $L_{4-5}$ level; $(\boldsymbol{B})$ sagittal reconstruction - degenerative stenosis at $L_{4-5}$ level

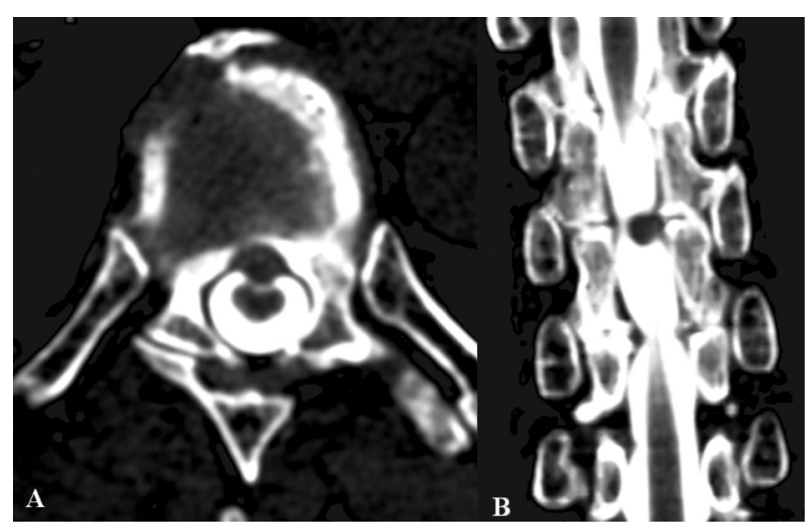

Figure 2. CT-assisted myelography: (A) axial view at $T_{h_{7-8}}$ level; (B) sagittal reconstruction - degenerative stenosis at $T h_{7-8}$ level

Case 3: Sixty-five year old female who suffered from long-lasting back pain that, occasionally, irradiated to the gluteal region and the antero-lateral surfaceof both thighs accompanied by numbness. One day prior to hospitalization, upon physical exertion she felt acute intensive pain in the thoraco-lumbar region, followed by numbness, stiffness and weakness of the legs that got completely paralyzed within hours. The lumbo-dorsal CT-assisted myelography demonstrated degenerative compression at $\mathrm{Th}_{7-8}$ level with laminar, facet and yellow ligament hypertrophy accompanied by severe central degenerative stenosis at $\mathrm{L}_{4-5}$ causing complete lower stop of the contrast agent (Figure 1 and 2).

One-stage surgical decompression was performed at $\mathrm{Th}_{7-8}$ followed by $\mathrm{L}_{4-5}$ level. Degenerative stenosis with laminar, facet and yellow ligament hypertrophy was found at both levels.

\section{DISCUSSION AND CONCLUSIONS}

According to the published data, the variety of clinical symptoms typical of the tandem compression of the spinal cord and cauda equin can lead to incomplete diagnosis $(2,3,7)$. In these cases, the detection of the thoracic compression can be omitted due to different factors:
1. The hypereflexia and leg spasticity caused by the myelopathy can be overlapped by the symptoms resulting from the compression of the cauda equina and the nerve roots $(3,7)$. All patients in our series demonstrate excitatory and depressed sensory redicular symptoms. Two of the patients showed motor deficits and absent tendon reflexes of the lower extremities, and three of them presented with more or less obvious signs of myelopathy.

2. Patients with compression of the epiconus and conus medullaris (from $\mathrm{Th}_{10}$ to $\mathrm{L}_{2}$ ) resemble the clinical presentation of lumbar radiculopathy $(8,9)$. Toribatake et al. published a series of 15 patients with similar lesion localizations. All patients presented with unilateral or bilateral muscle atrophy and sensory deficit, in $87 \%$ - absence of tendon reflexes, in 67\% — bowel and bladder disturbances and in only $20 \%$ - pathological reflexes (9). The compression at $\mathrm{L}_{1}-\mathrm{L}_{2}$ level typically presents with pain in the gluteal region and the antero-lateral surface of the thighs as well as positive femoral nerve stretch test, especially, when LasPgue sign is negative (9). Similar clinical presentation was observed in our patient $\mathrm{N}^{\circ} 1$.

3. Primary degenerative stenosis of the thoracic spine is relatively rare. Older patients often harbor asymptomatic cervical and/or thoracic degenerative stenosis that are not amenable to surgical intervention $(1,9)$. This is why physicians are focused on the clinically manifested lumbar pathology and, occasionally, omit the more superior compression (10).

All cases with clinically manifested lumbar spinal stenosis must undergo thorough neurological examination. If any minor myelopathic signs are present, it is mandatory to perform MRI of the entire spine to rule out compression of the spinal cord that can eventually compromise the treatment strategy and result in poor outcomes.

The timing and the surgical strategy in cases with tandem compression of the spinal cord and cauda equina that lead to neurological deficits in the lower extremities is a matter of debate. Some authors advocate initial surgery of the spinal cord compression, especially in urgent cases that are not suitable for one-staged procedure. In our series, we performed one-staged procedures in all cases with tandem thoracic and lumbar degenerative compression. We first addressed the thoracic lesion. We operated on the patient with combined thoracic meningioma and degenerative lumbar spinal stenosis at two separate stages as we first removed the thoracic compression.

\section{Abbreviations:}

HIJ - hypertrophy of the intervertebral joint; HYL - hypertrophy of the yellow ligament;

HVL - hypertrophy of the vertebral lamina;

DH - disc herniation 


\title{
Sažetak
}

\section{TANDEM KOMPRESIJA KIČMENE MOŽDINE I KAUDE EKVINE}

\author{
Zhelyazkov Christo, ${ }^{1}$ Davarski Atanas, ${ }^{1}$ Kitova Tanya, ${ }^{2}$ Kehayov Ivo, ${ }^{1}$ Kitov Borislav ${ }^{1}$ \\ ${ }^{1}$ Department of Neurosurgery, Medical University, Plovdiv, Bulgaria \\ ${ }^{2}$ Department of Anatomy, Histology and Embriology, Medical University, Plovdiv, Bulgaria
}

Cilj: Analiza i prikaz slučajeva tandem kompresije kičmene moždine i kaude ekvine.

Materijal i metode: Predmet posmatranja su četiri pacijenta sa istovremenom kompresijom kičmene moždine i kaude ekvine, koji su primljeni na Kliniku za neurohirurgiju Univerzitetske bolnice Sveti George, Plovdiv, u Bugarskoj, tokom perioda Mart 2012 Mart 2014. Prosečna starost pacijenata je 60,5 godina (47-72).

U prvom slučaju levostrana paramedijalna diskus hernija, pronađena je na nivou $\mathrm{L}_{1-2}$ i $\mathrm{L}_{4-5} \mathrm{u}$ kombinaciji sa pratećom stenozom, u drugom slučaju, desnostrana paramedijalna diskus hernija na nivou $\mathrm{Th}_{12}-\mathrm{L}_{1}$ kao $\mathrm{i}$ degenerativna stenoza na nivou od $\mathrm{L}_{3-4}$. $\mathrm{U}$ trećem slučaju, nađena je naglašena degenerativna kompresija na

\section{REFERENCES}

1. Teng P, Papatheodorou C. Combined cervical andlumbar spondylosis. Arch Neurol.1964; 10: 298-307.

2. Hioki A, Miyamoto K, Hosoe H, Fukuta S, Shimizu K. Two-stage decompression for combined epiconus and cauda equina syndrome due to multilevel spinal canal stenosis of the thoracolumbar spine: a case report. Arch Orthop Trauma Surg. 2008; 128(9): 955-8.

3. Takeuchi A, Miyamoto K, Hosoe H, Shimizu K. Thoracic paraplegia due to missed thoracic compressive lesions after lumbar spinal decompression surgery: report of three cases. J Neurosurg. 2004; 100 (1 Suppl Spine): 71-4.

4. Kim BS, Kim J, Koh HS, et al. Asymptomatic cervical or thoracic lesions in elderly patients who have undergone decompressive lumbar surgery for stenosis. Asian Spine J.2010; 4(2): 65-70.

5. Valls PL, Naul LG, Kanter SL. Paraplegia after a routine lumbar laminectomy: report of a rare complication and successful management. Neurosurgery.1990; 27(4): 638-40.

\author{
Correspondence to/Autor za korespondenciju \\ Ivo Kehayov \\ Department of Neurosurgery \\ 15A Vassil Aprilov Blvd, Plovdiv 4000, Bulgaria \\ Emaildr.kehayov@gmail.com
}

nivou $\mathrm{Th}_{7-8} \mathrm{i}$ centralna stenoza na nivou $\mathrm{L}_{4-5}$, a u poslednjem slučaju degenerativna stenoza na nivou $\mathrm{L}_{3-5} \mathrm{i}$ kičmeni meningeom na nivou $\mathrm{Th}_{9-10}$.

Rezultati: Klinički znaci istovremene kompresije kičmene moždine i kaude ekvine su bili ispitani. Ovi znaci mogu obmanuti lekara u dijagnostici kičmene lezije i tako rezultirati neodgovarajućim hirurškim strategijama.

Zaključak: Uključivanje kičmene moždine mora biti klinički potvrđeno da bi isključilo lezije u grudnom regionu. Kada su lumbalni pregledi nepotpuni ili ne uspevaju da objasne kliničke simptome određenog pacijenta, savetuje se magnetna rezonanca cele kičme.

Ključne reči: tandem kompresija, spinalni tumor, torakalna stenoza, lumbalna stenoza.

6. Ko SB, Lee SW, Shim JH. Paraplegia due to missed thoracic meningioma after laminotomy for lumbar spinal stenosis: report of two cases. Asian Spine J. 2011; 5(4): 253-7.

7. Fushimi K, Miyamoto K, Hioki A, Hosoe H, Takeuchi A, Shimizu K. Neurological deterioration due to missedthoracic spinal stenosis after decompressivelumbal surgery:A report of six cases of tandem thoracic and lumbar spinal stenosis. Bone Joint J.2013; 95-B(10): 1388-91.

8. Toribatake Y, Baba H, Kawahara N, Mizuno K, Tomita K.The epiconus syndrome presenting with radicular-type neurological features. Spinal Cord. 1997; 35(3): 163-70.

9. Lee S-Ho, Seokmin Choi S. L1-2 Disc Herniations: Clinical Characteristics and Surgical Results. J Korean Neurosurg Soc. 2005 (38): 196-201.

10. Wood KB, Garvey TA, Gundry C, Heithoff KB. Magnetic resonance imaging of thethoracic spine: evaluation of asymptomatic individuals. J Bone Joint Surg. 1995; 77(11): 1631-8.

11. Barnett GH, Hardy RW Jr, Little JR, Bay JW, Sypert GW. Thoracic spinal canal stenosis. J Neurosurg.1987; 66(3): 338-44. 